\title{
New Research on Mani’s Book of Giants
}

\author{
ENRICO MORANO (Turin/Italien)
}

When I was asked to translate into Italian the fragments of Mani's Book of Giants for the third volume of Il Manicheismo ${ }^{1}$ I decided to try to give the fragments in a sort of "sequences", which may reflect the original development of the "plot". The task proved to be very difficult and the result, quoted below, may well be object of criticism, but I think the legibility of this important work by Mani may have improved. ${ }^{2}$

In Kephalaia 5, 25 the Book of Giants is missing from the list of Mani's works given there, and there appears instead a writing tlaice nnparthos "on account of/for/at request of the Parthians". This has puzzled many scholars, linking misteriously this work with the Parthians. Moreover, one cannot understand why in a list of writings by Mani should stand, instead of a title, a general denomination such as "a writing for the Parthians". I am glad to quote here a solution offered to me by PAVEL LURJE: ${ }^{3}$ the Coptic rendering "writing on account of/for the Parthians" in the place of "Book of Giants" could be just a result of confusion of two meanings of Iranian pahlaw(ān) 1. 'Parthia(n)' and 2. 'hero, athlete', which could suit the meaning 'giant'.

There follows a list of the sequences proposed, a complete concordance of the published fragments, and the description of some fragments, still unpublished, which may belong to the Book of Giants.

\section{Dramatis Personae}

The Living Spirit - one of the Manichaean gods of the "second creation" Rex Honoris/Yima (?) - one of the 5 sons of the Living Spirit. In Mani's Book of Giants a transposition of the Jewish God (in Coptic and Sogdian texts respectively)

Virōgdād/Baraq'el — one of the leaders of the Watchers

Māhawai — a Giant, son of Virōgdād

Šahmīzād — one of the leaders of the Watchers

1 MORANO 2008, pp. 70-107 and 367-373, q.v. for earlier literature.

2 The fragments were scattered in various articles and the editors did not often try to locate the fragments in the book.

3 Private e-mail 6 May 2009. 
Sāhm/Ohyah — son of Šahmīzād

Pāt-Sām (or Narīmān)/Ahyah — son of Šahmīzād

Atnabīšs, Hōbabīš - Giants (their names are connected with Utnapishtim and Humbaba of the Gilgameš saga)

Enoch - the great-grandfather of Noah, one of the three people taken up to Heaven while still alive. He is the protagonist of several apocryphal books of the Old Testament

The 4 Archangels: Michael, Gabriel, Raphael, Uriel

Watchers/Egrēgoroi/demons

Giants

NB:

MBG = Mani's Book of Giants; $\mathrm{ABG}=$ Aramaic Book of Giants (Qumran)

SEQ. 1 - Rebellion in the watchpost of the Rex Honoris. 200 demons (= watchers) fall to earth. Their descent from heaven stirs up the other heavenly beings. They descend because of the beauty of the women they saw there, and they reveal forbidden arts and heavenly mysteries.

[MBG (references or quotations): Text L (Coptic) + Text M (Coptic) + Text P (Coptic) + Text J (Middle Persian) + Text K (Sogdian) + Text X (Parthian); Text Zu4 (Uigur).]

[Ref. to the Bible and pseudoepigraphical literature: Gen., 6, 2, and 11-12; 1 Enoch, 6, 1-2; 7-8; 9, 8; Jub., 5, 1 and 5, 5, 2-3.]

[Ref. to ABG: 4Q531 5]

SEQ. 2 - Šahmīzād (one of the fallen watchers) begets two Giants sons: Sähm (=Ohyah) and Pāt-Sām (=Narimān or Ahyah); other demons and Yaksas beget the rest of the Giants.

[MBG (references or quotations): Text H (Sogdian); Text O (Arabic).] [Ref. to the Bible and pseudoepigraphical literature: 1 Enoch, 6, 3; 7; 9, 7.]

SEQ. 3 - Giants' deeds. First warnings from Heaven. The Giant Māhawai, son of one of the Watchers who descended to earth, hears (possibly in a dream) a cautioning voice while flying along at sunrise and is guided to safety by Enoch's voice, who warns him to descend before the sun sets; his wings are on fire. Back to earth, he hears again the heavenly voice, which leads him to Enoch. Sähm and Māhawai have a contest, and someone reassures Măhawai that he will be protected from Sāhm.

[MBG: Text A, Fr. c (Middle Persian); Text B (Uigur); Text C (Sogdian).] [Ref. to ABG: 4Q203 1, 2, 3, 5 (?)]

SEQ. 4 - The Giants begin robbing wives and killing one another and other creatures. Sähm has a dream in which a tablet was thrown in the water. It seems to have borne three signs foreshadowing anguish, escape and destruction. Narimann has 
a dream in which he sees a garden full of trees in rows. Enoch is asked to interpret the dream: the trees are the Watchers and the Giants.

[MBG: Text A, Fr. j (Middle Persian); Text Zu3 (Uigur); Text D (Middle Persian).]

[Ref. to ABG: 1Q23 9+14+15; 2Q26; 6Q8 2]

[Ref. to the Bible and pseudoepigraphical literature: 1 Enoch, 7, 3-5. Midrash of Shemhazai and 'Aza'el.]

SEQ. 5 - The 4 Archangels (?) bring the earth's complaint before the Rex Honoris (=Yima?) and honour him. Enoch acts as mediator. The demons assemble fearful before him and ask for mercy. Apparently they promise to reform their ways.

[MBG: Text V (Sogdian); Text E (Sogdian).]

SEQ. 6 - Enoch (?) warns the demons that they will be taken through the fire to face eternal damnation and describes how the righteous will fly over the fire of damnation and rejoice.

[MBG: Text F (Middle Persian).]

SEQ. 7 - Enoch's message to the demons. Enoch gives a message to the demons and their children, telling them that they will have no peace, and that they will see the destruction of their children. They will rule for 120 years. Then he predicts an era of earthly fruitfulness.

[MBG: Text A, Fr. 1 (Middle Persian).]

[Ref. to ABG: 1Q23 1+6+22]

[Ref. to the Bible and pseudoepigraphical literature: 1 Enoch, 14, 6; 16, 3; Jub., 4, 22; 1 Enoch 10, 19 (?)]

SEQ. 8 - Enoch's messages to demons and giants. Sāhm's dream. Māhawai (?) comes with two stone tablets. He has brought them in order to share the contents of one tablet, pertaining to the demons, with the giants. Sahmīzād tells him to read the writing by Enoch. Sähm exhorts the other giants to cheer up and to eat, but they are too sorrowful to eat and fall asleep instead. Sähm has a dream: he came above in the sky, and sees the water of the earth consumed with heat and a demon of wrath comes out of the water. He then sees the heavenly rulers.

[MBG: Text W (Middle Persian).]

[Ref. to ABG: 4Q203 7 B II (?); 4Q203 8; 6 Q8 1; 4Q530 6 I (?)]

SEQ. 9 - Sāhm and Narimān prepare to fight. Someone (Enoch?) tells how he saw some (the Giants?) who were weeping and lamenting and many others who were sinful rulers. At this point one could insert a recently published Uigur text, in which Sähm kneels down and calls upon the Sun God, imploring mercy for his sins.

[MBG: Text A, Fr. k; Text A, Fr. g (Middle Persian); Text Zu1 (Uigur); Text Zu6 (Uigur).]

[Ref. to ABG: 4Q530 6 (?).] 
SEQ. 10 - The demons capture some "heavenly helpers". As a result, the Angels descend from heaven, terrifying the two hundreds demons, who take human form and hide among human beings. The Angels separate them and set a watch over them; then they separate the giants from the demons and lead them in thirty-two distant towns prepared for them by the Living Spirit. These people invented arts and crafts. Harsh fight between the 4 Angels and the 200 demons. Many are killed, among them hundreds of thousands of Righteous, because of fire, naphta and brimstone used by the Angels in the battle. The Angels protect Enoch. Electae and Auditrices are ravished and other beautiful women are forcibly married. The battle goes on. Atnabīs fights strongly and three giants are killed. An Angel, called "Great Angel", "royal Messenger of the Gods", kills and destroys.

[MBG Text G (Sogdian); Text A, Fr. i; Text T (Parthian); Text R (Coptic); Text Q (Coptic); Text Zp (Parthian)?; Text Y (Parthian); Text N (Parthian); Text S (Coptic)]

[Ref. to the Bible and pseudoepigraphical literature: 1 Enoch, 17, 1.]

[Ref. to ABG: 4Q531 4 (?).]

SEQ. 11 - Doctrinal text on the 5 elements.

[MBG (?) Text A, Fr. e; Text A, Fr. b; Text A, Fr. h.]

SEQ. 12 - Exegetic text on the Hearers.

[MBG (?) Text A, Fr. h; Text A, Fr. f; Text A, Fr. d; Text A, Fr. m; Text A, M 911; Text A, Fr. n.]

\section{Texts of uncertain position}

Text I (Sogdian): someone (possibly a Giant) praises the Giants' (especially Sāhm's and his brother's) strength and immortality. The verso was believed to be blank, but in fact a piece of paper was stuck to the sheet ${ }^{4}$, hiding the text. After the restoration the text can be read almost completely ${ }^{5}$, but its interpretation is difficult: it is said that neither from a pardon, nor from a pious death (?) a complete salvation can be; not the Giants, not the arhants, not the rulers, not the kings $[\ldots]$

Edition of M 500n/V/

lines missing

$\operatorname{M500n(1)/V/1/[\ldots ](ty)}{ }^{\circ}\left({ }^{\prime}\right)[11-12]$

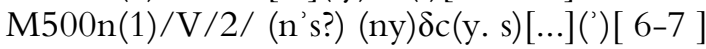

$\operatorname{M500n}(1) / \mathrm{V} / 3 /$ wxnš $\beta\left(\mathrm{r}^{\prime}\right) \mathrm{t}^{\circ}$ 'rțy (pyš)ṭ c(n)

M500n(1)/V/4/ ny prm'n ny z'rcnwq

4 See below fig. 1.

5 See below fig. 2. 


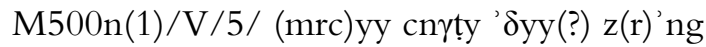

$\operatorname{M500n}(1) / \mathrm{V} / 6 /$ nyst ${ }^{\circ}$ ny kwyšt ny $(\mathrm{rh})$ nd ${ }^{\circ}$

$\mathrm{M} 500 \mathrm{n}(1) / \mathrm{V} / 7 /$ ny xšywny(ț) ${ }^{\circ}$ ny xwț ${ }^{\prime} w t^{\circ}$ ny

end of page

Text $\mathbf{U}$ (Parthian): in this text three kings and heroes of the Zoroastrian period are mentioned. Mani must have identified the heroic period with that of the antedeluvian patriarchs. If this fragments belongs to the Book of Giants, it should perhaps be placed at the beginning, in a kind of introduction to the Manichaean history of origins.

Text Zp2 (Parthian): quotations in a Sogdian text from the Parthian version of the Book of Giants ( $c^{\prime} n w w y y^{\prime} \beta \gamma y y n(p)[\gamma k y \gamma] \underline{h}$ 'as in the Lord's Book'6). The evil lives of the Giants are mentioned, and the consequences they brought to the future generations. At one point it is said that Ohya dies, with his brother, at the feet of his dearest (father?). It is therefore reasonable to think that these quotations come from the final part of the Book of Giants (Seq. 10)

Text Zs1 (Sogdian): the text deals with the story of the abortions, and Pēsūs and Saklūn. It is written in the second page of a bifolio, on the first page of which a portion of the Book of Giants is written (text G), therefore it must have belonged to the same book. It could be placed at the beginning, being a sort of cosmogonical prologue.

Text Zs2 (Sogdian): very short fragment, in which Hōbābīs is quoted. The text seems to contain the end of a speech, probably related to text A, fr. j (Seq. $4)$.

Text Zu2 (Uigur): too fragmentary to allow any placement.

Text Zu5 (Uigur): the headline relates the text to the Hearers. Possibly to be related to the Exegetic text on the Hearers which concluded the Book (Seq. 12).

\section{List of the published fragments of Mani's Book of Giants}

Text A (Middle Persian)

[M 101 a-n e M 911]. 15 fragments from the same manuscript published by HENNING 1943, pp. 56-65, in the following sequence: c, j, l, k, g, i (text of the Book of Giants), e, b, h (Discourse on the Five Elements), f, a, d, m, M 911, n (Parables on the Hearers).

$A c=$ Seq. $3 ; A j=$ Seq. $4 ; A l=$ Seq. $7 ; A k=$ Seq. $9 ; A g=$ Seq. $9 ; A i=$ Seq. 10; Ae, b, h = Seq. 11; A h, f, d, m, M 911, n = Seq. 12.

Text B (Uigur) [Mainz 317. vON LE COQ 1922, p. 23] = Seq. 3.

6 I thank PAVEL LURJE and NiChOlas Sims-Williams for this clever emendation. 
Text C (Sogdian) [M 648. HenNing 1943, pp. 65-66] = Seq. 3.

Text D (Middle Persian) [M 625c. HenNing 1934, p. 29; Engl. transl. in HENNING 1943, p. 66.] = Seq. 4.

Text E (Sogdian) $[$ M $8005=$ T III 282. HenNING 1943, p. 66] = Seq. 5.

Text F (Middle Persian) [M 6120/I = T II D II 164. HenNing 1943, pp. 668] $=$ Seq. 6 .

Text G (Sogdian) [M 7800/I = T II. HENNING 1943, pp. 68-9] = Seq. 10.

Text H (Sogdian) [So 14638/I/R/1-17 = T II S 20. HENNING 1943, pp. 6970] $=$ Seq. 2 .

Text I (Sogdian) [M 500n/R. HenNing 1943, 70] = Fragments of uncertain position.

Text J (Middle Persian) [M 5750/V/II/1-5 = T II D 120. HenNING 1943, p. 70] $=$ Seq. 1 .

Text K (Sogdian) [M 363. HenNing 1943, pp. 70-1] = Seq. 1.

Text L (Coptic) [Kephalaia, 171, 16-17. HenNING 1943, p. 71] = Seq. 1.

Text M (Coptic) [Kephalaia, 92, 24-31. HenNING 1943, p. 71] = Seq. 1.

Text N (Parthian) $[\mathrm{M} 35 / \mathrm{V} / 3-18,=$ M 740/V/1-6. HenNing 1943, pp. $71-$ 2] $=$ Seq. 10 .

Text O (Arabic) [al-Gaḍanfar, ed. SACHAU of Ātār al-bāqiyah of al-Bīrūnī (SACHAU 1878, Intr., p. XIV); HENNING 1943, p. 72] = Seq. 2.

Text $\mathbf{P}$ (Coptic) [Kephalaia, 93, 23-28; Engl. transl. HeNNING 1943, p. 72] = Seq. 1.

Text Q (Coptic) [Coptic Manichaean Psalmbook, 142, 7-9; Engl. transl. HENNING 1943, p. 72] = Seq. 10.

Text R (Coptic) [Coptic Manichaean Homilies, 68, 18-9; Engl. transl. HeNNING 1943, p. 72] = Seq. 10 .

Text S (Coptic) [Kephalaia, 117, 1-9; Engl. transl. HenNING 1943, p. 72] = Seq. 10.

Text T (Parthian) [M 291a. HenNing 1943, p. 73] = Seq. 10.

Text U (Parthian) [M 4990/R = T II D 58, V left blank. HenNING 1943, pp. 73-4] $=$ Fragments of uncertain position.

Text V (Sogdian) [M 692, Sogdian. HenNing 1943, p. 74] = Seq. 5.

Text W (Middle Persian), often quoted as L (= Leningrad) [S I O/120/I. SUNDERMANN 1984, pp. 495-502] = Seq. 8. 
Text X (Parthian) [M 8280. SUNDERMANN 1973, pp. 76-77, 11. 1523-42] = Seq. 1.

Text Y (Middle Persian) [M 5900. SundermanN 1973, pp. 77-78, 11. 154982] $=$ Seq. 10.

Text Zp1 (Parthian) [M 413 + M 2086. ColditZ 1987, pp. 297-9 1l. 13751] $=$ Seq. 10 .

Text Zp2 (Parthian) [M 813/I. MORANO 2009, pp. 325-330. = Fragments of uncertain position.

Text Zs1 (Sogdian) $[\mathrm{M} 7800 / \mathrm{II}=\mathrm{T}$ II. SUNDERMANN 1994, pp. 45-6] = Fragments of uncertain position.

Text Zs2 (Sogdian) [Ōtani 7447/R + 7468/R. KUDARA/SUNDERMANN/ YOSHIDA 1997, p. 139] $=$ Fragments of uncertain position.

Text Zu1 (Uigur) [Mainz 344a (= T I $\alpha$ ). WiLkens 2000, pp. 157-8] = Seq. 9.

Text Zu2 (Uigur) [U 288 (=T I $\alpha \times 24$ ). WiLKens 2000, p. 159] $=$ Fragments of uncertain position.

Text Zu3 (Uigur) [U 217 (= T I $\alpha$ ). WiLKens 2000, pp. 161-3] = Seq. 4.

Text Zu4 (Uigur) [Mainz 347. Wilkens 2000, pp. 165-7] = Seq. 1.

Text Zu5 (Uigur) [U 269. WiLKENS 2000, p. 169] = Fragments of uncertain position.

Text Zu6 (Uigur) [U 222 (= T I D). WiLKENS 2000, pp. 171-3] = Seq. 9.

Unpublished Middle Iranian fragments which may belong to the Book of Giants

- So 10700a + So 20193a (Sogdian) [RECK 2006 N. 60]

Two joining fragments, giving 17 incomplete lines. The context is very poor. The Giant Sāhm $\left(s^{\prime} x m k w y\right)$ is often mentioned. Possibly a dialog between giants, when they became unlawful $\left(p \delta^{\prime} t y\right)$ and started to kill $\left(p t y^{\prime}-x w^{\prime} \gamma\right)$.

A messenger from [...] ('zynt MN [...]) is also mentioned (one of the Archangels? Enoch?). The fragment could perhaps be placed in Seq. 3 or Seq. 4. 
- So 10701a (Sogdian) [RECK 2006 N. 61]

From the same manuscript as So $10700 \mathrm{a}+$, and possibly from an adjacent page. A Giant (Sāhm?) is mentioned and the ocean ( $m x^{\prime}$ smwtry) seems to be red (because of the blood?).

- So 14255 (Sogdian) [RECK 2006 N. 134]

- So 14256 (Sogdian) [RECK 2006 N. 135]

Both texts, from the same manuscript, describe the fallen abortions and the demonic couple Pēsūs and Šaklūn devouring the abortions' offsprings, so as to eat as much light as they can. The text is very similar to M 7800/II (text Zs1). If it belonged to the Book of Giants, it could possibly be placed, like Zs1, in a kind of cosmogonical prologue to the book.

\section{- So 20193b (Sogdian) [RECK 2006 N. 319]}

From the same manuscript as So 10700a, So 10701a and So 20193a. Again, the Giant Sāhm is mentioned, but the context is very poor.

\section{Bibliography and Abbreviations}

Boyce, Mary (1960): A Catalogue of the Iranian Manuscripts in Manichean Script in the German Turfan Collection, Berlin.

COLDITZ, IRIS (1987): Bruchstücke manichäisch-parthischer Parabelsammlungen. In: Altorientalische Forschungen XIV, pp. 274-313.

Henning, Walter BRuno (1934): Ein manichäisches Henochbuch. In: Sitzungsberichte der Preußischen Akademie der Wissenschaften V, pp. 27-35 [= HENNING SP I, pp. 341-49].

Henning, Walter Bruno (1943): The Book of the Giants. In: Bulletin of the School of Oriental and African Studies 11/1, pp. 52-74 [= HENNING SP II, pp. 115-37].

Henning SP = Henning, Walter Bruno, (Boyce, MARy et al. eds.) (1977), Selected Papers, I-II Téhéran/Liège (Acta Iranica, 2. sér, 14-15; Hommages et Opera Minora, V-VI).

KudARA, Kōgi / Werner Sundermann / Yutaka Yoshida (1977): Iranian Fragments from the Ötani Collection. Iranian Fragments unearthed in Central Asia by the Otani Mission and kept at the Library of Ryükoku University. Text Volume. Facsimile Volume. Kyoto.

Le CoQ, Albert von (1922): Türkische Manichaica aus Chotscho, III. Nebst einem christlichen Bruchstück aus Bulayïk, Abhandlungen der Preußischen Akademie der Wissenschaften, Berlin.

Morano, EnRico (2008): Il Libro dei Giganti di Mani. In: GHerardo GnOli (ed.), Il Manicheismo. Volume III. Il mito e la dottrina. Testi manichei dell'Asia Centrale e della Cina, Milano, pp. 71-107 and 367-373. 
Morano, Enrico (2009): 'If they had lived ...' A Sogdian-Parthian Fragment of Mani's Book of Giants. In: Werner Sundermann / Almut Hintze / FRANÇOIS DE BlOIS (eds.), Exegisti monumenta, Festschrift in Honour of Nicholas Sims-Williams, Wiesbaden, pp. 325-330.

ReCK, CHRistiane (2006): Mitteliranische Handschriften. Teil 1: Berliner Turfanfragmente manichäischen Inhalts in soghdischer Schrift, Stuttgart (VOHD XVIII, 1).

SACHAU, CARl EDUARD (1878) (ed.): Chronologie orientalischer Völker, von Albêrûnî, Leipzig.

SUndermann, WeRner (1973): Mittelpersische und parthische kosmogonische und Parabeltexte der Manichäer, Berlin (Berliner Turfantexte 4).

Sundermann, Werner (1984): Ein weiteres Fragment aus Manis Gigantenbuch. In: Orientalia J. Duchesne-Guillemin Emerito Oblata, Leiden (Acta Iranica 23; 2e sér., Hommages et Opera Minora IX), pp. 491-505.

SundermanN, WeRner (1994): Mani's ,Book of the Giants' and the Jewish Books of Enoch. A case of terminological difference and what it implies. In: SHAUL SHAKed / AmNON NetZer (eds.), Irano-Judaica III, Jerusalem, pp. 40-48.

Wilkens, Jens (2000): Neue Fragmente aus Manis Gigantenbuch. In: Zeitschrift der Deutschen Morgenländischen Gesellschaft CLI, pp. 133-176. 
Fig. 1

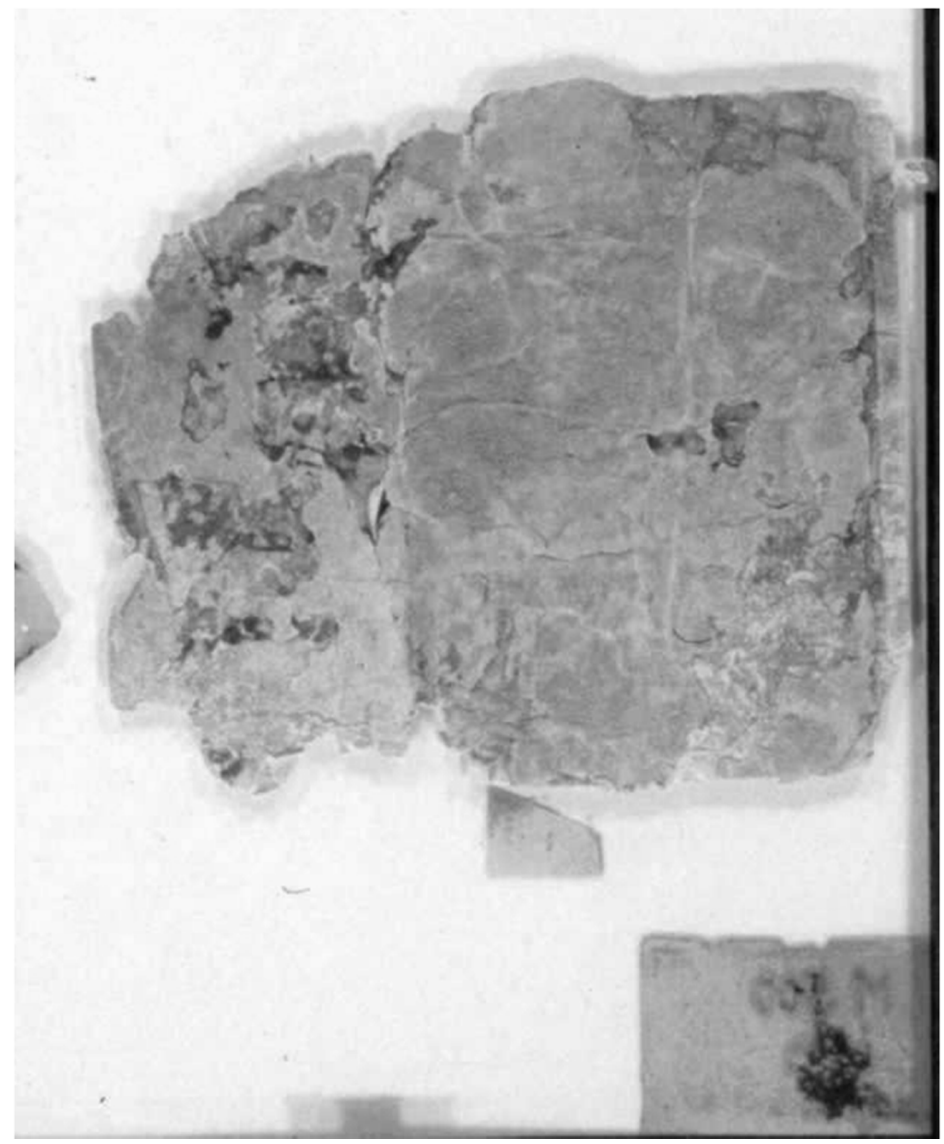

$\mathrm{M} 500 \mathrm{n} / \mathrm{V}$ before restoration

(Photo Staatsbibliothek zu Berlin, Preußischer Kulturbesitz) 
Fig. 2

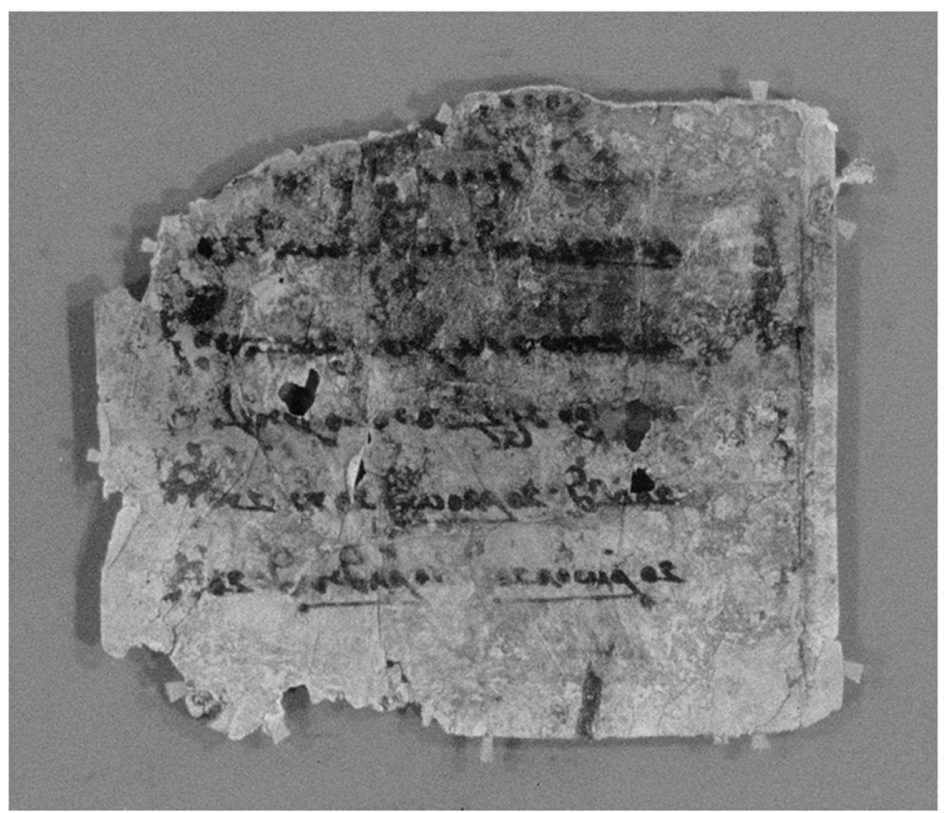

$\mathrm{M} 500 \mathrm{n} / \mathrm{V}$ after restoration

(Photo Staatsbibliothek zu Berlin, Preußischer Kulturbesitz) 
